\title{
Physiologic parameters of soybean of determinate and indeterminate growth habit subjected to levels of soil moisture
}

\author{
Carlos Sebastião Machado Júnior ${ }^{(1)}$, Cláudio Ricardo da Silva(1), Maria Cristina Sanches ${ }^{(1)}$ \\ Osvaldo Toshiyuki Hamawaki ${ }^{(1)}$ and Larissa Barbosa de Sousa(1)
}

\begin{abstract}
(1)Universidade Federal de Uberlândia, Instituto de Ciências Agrárias, Avenida Amazonas, s/no, Umuarama, CEP $38400-902$ Uberlândia, MG, Brazil. E-mail: casemaju@yahoo.com.br, claudio@iciag.ufu.br, sanchesmc@gmail.com, hamawaki@umuarama.ufu.br, larissa@iciag.ufu.br
\end{abstract}

\begin{abstract}
The objective of this work was to evaluate the physiological and production parameters of soybean (Glycine max) cultivars of determinate and indeterminate growth habits, in three levels of soil moisture. Three cultivars of determinate growth habit and three of indeterminate growth, at the beginning of the reproductive stage, were subjected to three levels of soil moisture: control, moisture at field capacity; moderated, $50 \%$ of the control level; and severe, $25 \%$ of the control level. Leaf gas exchange, xylem-water potential, chlorophyll content, chlorophyll a fluorescence, plant dry matter, and grain yield per plant were evaluated. The cultivars of indeterminate growth habit showed the greatest values for stomatal conductance and $\mathrm{CO}_{2}$ assimilation at the severe treatment, which led to the higher water consumption, in the morning, and to the lower xylem water potential, in the afternoon; however, there was no gain of soybean dry matter. In both growth types, the intensity and duration of the severe level of soil moisture were not able to change the chlorophyll fluorescence. Soybean cultivars of both growth habits, subjected to severe levels of soil moisture from flowering to pod insertion, show no significant change for dry matter and grain yield.
\end{abstract}

Index terms: Glycine max, chlorophyll, fluorescence, gas exchange.

\section{Parâmetros fisiológicos de soja de crescimento determinado e indeterminado submetida a níveis de umidade do solo}

\begin{abstract}
Resumo - O objetivo deste trabalho foi avaliar parâmetros fisiológicos e de produção de cultivares de soja (Glycine max) de hábitos de crescimento determinado e indeterminado, em três níveis de umidade do solo. Três cultivares de crescimento determinado e três de crescimento indeterminado, no início do estádio reprodutivo, foram submetidas a três níveis de umidade do solo: controle, umidade à capacidade de campo; moderado, $50 \%$ do controle; e severo, $25 \%$ do controle. Avaliaram-se as trocas gasosas, potencial de água no xilema, nível de clorofila, fluorescência da clorofila a, massa de matéria seca e a produção de grãos por planta. As cultivares de hábito de crescimento indeterminado apresentaram maior condutância estomática e assimilação de carbono no tratamento severo, o que levou ao maior consumo de água, no período da manhã, e ao menor potencial de água no xilema, à tarde; porém, não houve ganho de massa de matéria seca da soja. Em ambos os tipos de crescimento, a intensidade e a duração do nível severo de umidade não alteraram a fluorescência da clorofila. Cultivares de soja, de ambos os tipos de crescimento, submetidas a nível severo de umidade do solo, do período de florescimento até o de formação de vagens, não apresentam alteração significativa de produção de massa de matéria seca e de grãos.
\end{abstract}

Termos para indexação: Glycine max, clorofila, fluorescência, troca gasosa.

\section{Introduction}

Soybean [Glycine $\max (\mathrm{L}$.$) Merrill] is considered$ one of the most important crops in the world, with a yield of $241.84 \mathrm{Tg}$ (FAO, 2012). Currently, Brazil is the second largest producer of soybean, with $97.18 \mathrm{Tg}$ in the 2015/2016 harvest(IBGE, 2016).

Soybean can be classified, according to its growth habit, as determinate or indeterminate. In cultivars of determinate growth habit, the apical meristem stops the differentiation of new leaves after floral induction, while in cultivars of indeterminate growth habit, the differentiation of leaves occurs over some time after the floral induction (Tanaka \& Shiraiwa, 2009). In the last years, the search for soybean cultivars with indeterminate growth significantly increased in Brazil (Perini et al., 2012). This is due to the necessity of earlier sowing dates to allow of both the corn sowing as 
a second-crop and the reduction of the damage caused by Asian soybean rust, as plants with indeterminate growth habit have a more open canopy, which enables pesticide application to more easily reach the lower third of the plant.

The occurrence of abiotic stresses can reduce crop yield significantly, which restricts the dates and places for the planting of commercially important grainyielding species. The abiotic stress caused by water deficiency reduces soybean development and yield, caused by diminishing of leaf area (Sincik et al., 2008), and changings on photosynthesis (Fenta et al., 2012), and gas exchange characteristics (Liu et al. 2005; Bertolli et al., 2012; Catuchi et al., 2012; Li et al., 2013; Madhu \& Hatfield, 2014).

As for the tolerance to very low levels of soil moisture, some authors reported that cultivars with indeterminate growth habit show better ability to recover from this abiotic stress, as they continue to growth after the beginning of the floral stage, maintaining the potential to form new flowers and pods after a strong deficiency of soil moisture (Villalobos-Rodrigues \& Shibles, 1985). However, Tanaka \& Shiraiwa (2009), analyzing the morphophysiological differences in the leaves of both soybean growth habits, observed that plants of indeterminate growth habit showed a greater stomatal conductance than those of the determinate growth, in good soil-water availability, and attributed this fact to a greater stomata density in the leaves. They also reported that gas exchange characteristics should be taken into consideration in plant breeding programs for tolerance to low-moisture levels, since determinate growth cultivars wilt slower than those of indeterminate habit. However, the authors did not evaluate how plants woul respond to the exposure to soil moisture deficiency. Brevedan \& Egli (2003) analyzed the effect of short drought periods (less than 13 days) in a soybean cultivar, during seed filling, and reported $39 \%$ of yield losses .

Considering the responses of the growth habit as a consequence of soil-moisture deficiency can be of great value to improve plant breeding programs for tolerance to this stress.

The objective of this work was to evaluate the physiological parameters, dry matter accumulation, and grain yield of soybean cultivars of determinate and indeterminate growth habits subjected to different levels of soil moisture.

\section{Materials and Methods}

The experiment was carried out in the Capim Branco experimental farm $\left(18.88^{\circ} \mathrm{S}, 48.34^{\circ} \mathrm{W}\right.$, at $900 \mathrm{~m}$ altitude), of Instituto de Ciências Agrárias of Universidade de Uberlândia (UFU), in Uberlândia, MG, Brazil, from October 2014 to January 2015, in a greenhouse, in a completely randomized experimental design. For the physiological variables, a $3 \times 2$ factorial arrangement - with three levels of soil moisture, and two soybean growth habits - was used, with four replicates. For the determination of dry matter mass (root and shoot) and grain yield, a 3x6 factorial arrangement - three levels of soil moisture, and six cultivars - was used, with two and four replicates, respectively.

The treatments consisted of six cultivars, three of determinate and three of indeterminate growth habits, and the following three levels of soil moisture: control, moisture at field capacity; moderate, $50 \%$ of water volume applied to the control; and severe, $25 \%$ of water volume applied to control. The evaluated cultivars of determinate habit were UFUS Xavante, UFUS Carajás and MG/BR 46 (Conquista), and those of indeterminate habit were UFUS 6901, BRSMG 772 and BRSMG 7525. These cultivars were chosen because they are recommended for the region where the experiment was done.

Plastic pots of $12 \mathrm{dm}^{3}$ were used; they were filled with a mix of fine sand, soil, and Plantmax organic substrate at 1:1:1, which resulted in a substrate of sandyloam texture, with $4 \%$ organic mass. The workbenches where the pots were set had an electronically controlled drip irrigation system, and the drippers had a $7.2 \mathrm{~L} \mathrm{~h}^{-1}$ flow rate, with $98 \%$ uniformity distribution coefficient.

Sowing was done on October 10, 2014, with five seed per pot. After the CV stage (first cotyledon leaf), the seedlings were thinned to two seedlings of the same cultivar per pot. From the stage V2 (two completely developed trefoils) on, the pots were fertilized with 2.6 grams per pot every ten days, using $\mathrm{N}-\mathrm{P}_{2} \mathrm{O}_{5}-\mathrm{K}_{2} \mathrm{O} 20$ 10-10 formulation with micronutrients (Nutrigramas, Vitaplan, Comércio de Produtos Agropecuários, Nilópolis, RJ, Brazil).

Evaluation of water tension in the substrate was done using 24 tensiometers of $20 \mathrm{~cm}$ long, which were randomly placed in one replicate of each experiment. Water tension reading was done with a digital puncture manometer (Blumat Digital, Telfs, Austria). Irrigation 
before and after the period of the treatment application was done to maintain the water potential next to soilwater capacity in the pots, which was experimentally determined as a value between 5 and $15 \mathrm{kPa}$.

The levels of moderate an severe soil moisture were applied at 44 days after seed emergency (DAE), when plants were between the stages R1 (beginning of flowering ) and R3 (beginning of pod formation), and these levels were maintained for 13 days, finalizing at 57 DAE. The evaluation of the phenological stage was done according to the scale of Fehr \& Caviness (1977).

Meteorological data inside the greenhouse were obtained with a Vantage Pro2 automated meteorological station (Davis Instruments Corporation, Hayward, CA, EUA) programmed to report data every $10 \mathrm{~min}$. Data on air temperature $\left(0.5^{\circ} \mathrm{C}\right.$ accuracy), surfacesolar irradiance ( $5 \%$ accuracy), and relative air moisture (3\% of accuracy) were collected throughout the duration of the experiment. The water vapor pressure deficit $(\Delta \mathrm{e})$ was calculated with the data of air temperature and relative air moisture.

The assimilation of $\mathrm{CO}_{2}\left(\mathrm{~A}, \mu \mathrm{mol} \mathrm{CO} \mathrm{m}^{-2} \mathrm{~s}^{-1}\right)$, stomata conductance (gs, $\mathrm{mol} \mathrm{H}_{2} \mathrm{O} \mathrm{m}^{-2} \mathrm{~s}^{-1}$ ), and leaf temperature $\left(\mathrm{T},{ }^{\circ} \mathrm{C}\right)$ were analyzed in one trefoil of the middle third of each replicate by a Lcpro-4 infrared gas analyzer (Analytical Development Co., Hoddesdon, England). . However, only the Ufus Carajás (determinate habit) and the BRSMG 772 (indeterminate habit) cultivars were analyzed, due to the 1-hour window time frame available for the analyses of gas exchanges, limited to the equipment capacity of 24 plots per hour.

Chlorophyll measurements were made with the portable electronic measurer CFL-1030 clorofiLOG (Falker Automação Agrícola, Porto Alegre, RS, Brazil), which provides relative measurements of total chlorophyll (0 to 100) that correlates with total chlorophyll content (Rigon et al., 2012). Measurements were made in the morning $( \pm 8: 00 \mathrm{~h})$ and in the afternoon $( \pm 14: 00 \mathrm{~h})$, in the third and in the twelfth days after the water-regime treatments . At the same schedule, chlorophyll fluorescence was also estimated with a Mini-PAM modulated-light fluorimeter (Heinz Walz GmbH, Effeltrich, Germany). Minimum (Fo), maximum (Fm), and variable (Fm Fo) fluorescence values were obtained after $30 \mathrm{~min}$ of adaptation to darkness, with appropriate DLC-8 clips. Potential quantum yield of photosystem II was calculated from that data, with the following equation:
$\mathrm{Fv} / \mathrm{Fm}=(\mathrm{Fm}-\mathrm{Fo}) / \mathrm{Fm}$ (Lambers et al., 2008). The decrease of $\mathrm{Fv} / \mathrm{Fm}$ ratio is an indication of stress and damage to the thylakoid membranes (Prasad et al., 2008).

Xylem-water potential $(\Psi)$ was measured before dawn $( \pm 5: 00 \mathrm{~h})$ and in the afternoon $( \pm 14: 00 \mathrm{~h})$, using a 3005F01 Scholander pressure chamber (Soil Moisture Equipment Corp., Santa Barbara, CA, EUA). To do this, one of the trefoils of the upper third was detached from the plant and placed inside the pressure chamber, in order to measure its water potential.

After the applications of moderate and severe soil moisture treatment, dry matter mass of root and shoot was evaluated in two replicates of each treatment. Plants were harvested, roots were separated from shoots at the collar and dried at $65^{\circ} \mathrm{C}$ until constant mass was obtained. Grain yield per plant was obtained by weighing beans of all the remaining parcels (four replicates). All the data were subjected to the ShapiroWilk's test for normality of residues, and to the analysis of variance. The means were compared by the Tukey's test, using the software Assistat (Silva \& Azevedo, 2009).

\section{Results and Discussion}

Atmospheric conditions were not limiting to soybean crop in day periods, and air temperature, water vapor deficit, and solar radiation were, respectively, $23.3^{\circ} \mathrm{C}$, $0.755 \mathrm{kPa}$, and $192.5 \mathrm{~W} \mathrm{~m}^{-2}$, in the morning, and $29.2^{\circ} \mathrm{C}, 1.81 \mathrm{kPa}$ and $365.5 \mathrm{~W} \mathrm{~m}^{-2}$, in the afternoon. The increaseof water vapor deficit $(\Delta \mathrm{e})$ in soybean has been associated with the increase of plant transpiration rate. Gilbert et al. (2011) reported that values greater than $2.0 \mathrm{kPa}$ for water vapor deficit caused significant differences in the transpiration rate.

Stomata conductance was affected by severe soil moisture deficit both in the morning and in the afternoon, irrespective of growth habits (Figure 1). An increase of stomata conductance and of $\mathrm{CO}_{2}$ assimilation was observed in the control treatment (soil at field capacity) for both growth habits, in the afternoon, probably in response to water vapor deficit that increased from 0.75 to $1.81 \mathrm{kPa}$. There was a reduction of $\mathrm{CO}_{2}$ assimilation, with the increase of water restriction (moderate to severe treatments), similarly to the findings of Liu et al. (2005). However, in the severe treatment, there was a recovery of stomata 
conductance and $\mathrm{CO}_{2}$ assimilation for the cultivars of indeterminate growth habit.

Reduced transpiration by stomata closing, in plants under severe soil moisture stress, may be a desirable characteristic in soybean plants cultivated without irrigation, especially in arid regions, in order to save water in the initial stages of the crop, which enables a water supply to be available for later stages when water is most needed (Sinclair et al., 2005). Therefore, since the cultivars of indeterminate habit showed greater values of stomata conductance and $\mathrm{CO}_{2}$ assimilation, under severe drought treatment, they could also reach the wilting point more quickly.

Xylem-water potential $(\psi)$, in the morning, did not show significant interaction with growth habits of the soybean cultivars; however, the plants subjected to severe drought showed lower values - more negative ones - for this parameter (Table 1). However, in the afternoon, indeterminate growth habit cultivars showed lower xylem water potentials. This result can be attributed to greater stomata conductance in indeterminate growth habits, which had an increase of transpiration in the morning leading to a faster consumption of water contained in the substrate and, consequently, to a lower-water potential in the afternoon. Tanaka \& Shiraiwa (2009) observed that soybean with indeterminate growth habit has greater stomata conductance; however, the authors did not subject both growth habits to a severe soil moisture treatment. Notheless, these authors' findings help to explain the light increase of stomata conductance in the present work, in soybean of indeterminate habit subjected to severe stress, despite the different conditions of the experiments.
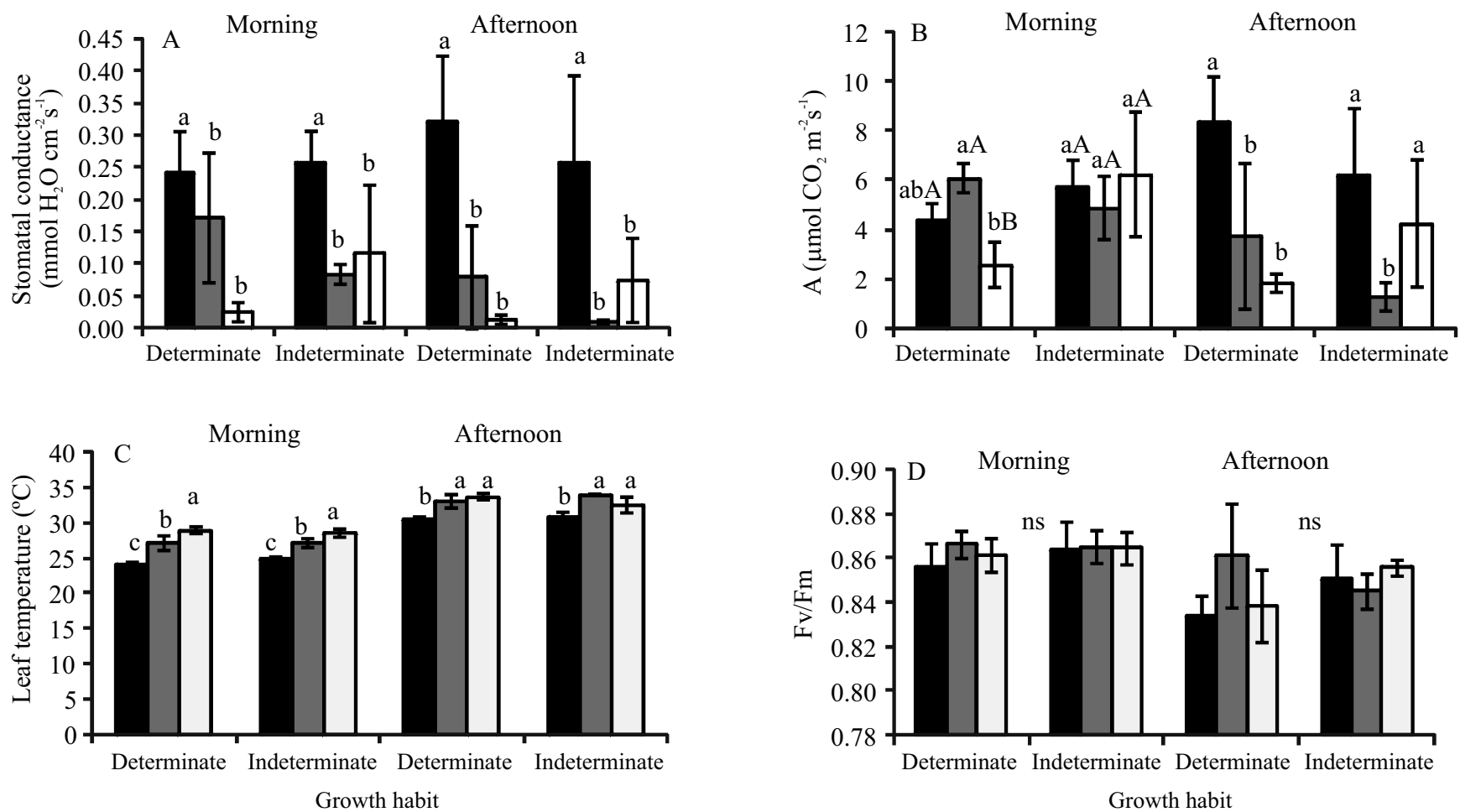

Growth habit

Control $\square$ Moderate $\square$ Severe

Figure 1. Stomata conductance (A), $\mathrm{CO}_{2}$ assimilation rate (B), leaf temperature (C), and photosystem II efficacy (PSII, FV/ Fm) (D) of soybean (Glycine max) cultivars of determinate (UFUS Xavante, UFUS Carajás, and MG/BR 46 Conquista) and indeterminate growth habits (UFUS 6901, BRSMG 772, and BRSMG 7225) subjected to the following treatments: control, soil moisture at field capacity; moderate stress, $50 \%$ of the control soil moisture; and severe stress, $25 \%$ of the control soil moisture. Uppercase letters refer to growth habit, lowercase letters refer to soil moisture level. Means with equal letters do

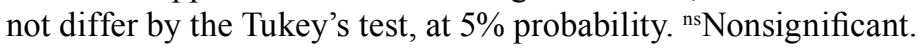


Leaf temperature was not affected by soybean growth habit; however, it had a significant increase in the severe treatment (Figure 1 C) because stomata closing contributed to leaf temperature rise, as shown by Inamullah $\&$ Isoda (2005), who reported a more rapid increase of leaf temperature in soybean than in other crops, such as cotton. The plants that were subjected to the control treatment had lower-leaf temperatures than the other two treatments because stomata remained open due to water availability.

Values of $\mathrm{Fv} / \mathrm{Fm}$ in a healthy plant are near 0.8 , but can be lower in consequence of abiotic stresses (Krause \& Weiss, 1991). In the present study, the values of $\mathrm{Fv} / \mathrm{Fm}$ varied from 0.83 to 0.87 , with no significant differences between treatments, meaning that the application of moderate and severe levels of soil moisture for 13 days was not sufficient to cause damage to the photosystem apparatus (Figure $1 \mathrm{D}$ ). The values of $\mathrm{Fv} / \mathrm{Fm}$ found in this study are greater than those reported by Bertolli et al. (2012), but similar to those found by Huang et al. (2006).

Dry matter mass of root, in both growth habits, showed no significant differences between treatments of soil moisture stress, although the means of the control treatment were greater than those of severe and moderate stresses (Figure 2). To obtain a high grain yield and high production of dry matter mass, plants require a high-stomata conductance over time, to allow of a greater $\mathrm{CO}_{2}$ assimilation per leaf area, under different conditions (Blum, 2009). Mass of shoot dry matter of both growth habits showed $30-45 \mathrm{~g}$ in the severe moisture treatment.

The lack of difference for the accumulation of root dry matter between both growth habits, subjected to the same levels of soil moisture stress, can mean that differences of assimilation by plants of indeterminate growth habit, in comparison to those of determinate growth, was used for other purposes than the

Table 1. Water potential ( $\Psi)$, in the morning and in the afternoon, of soybean (Glycine max) cultivars of determinate and indeterminate growth habits subjected to three levels of soil moisture (MPa).

\begin{tabular}{|c|c|c|c|c|c|c|}
\hline \multirow[t]{2}{*}{ Growth habit } & \multicolumn{3}{|c|}{ Morning } & \multicolumn{3}{|c|}{ Afternoon } \\
\hline & Control & Moderate & Severe & Control & Moderate & Severe \\
\hline Determinate & $\begin{array}{c}-0.09 \mathrm{Aa} \\
( \pm 0.03)\end{array}$ & $\begin{array}{c}-0.13 \mathrm{Aab} \\
( \pm 0.05)\end{array}$ & $\begin{array}{c}-0.25 \mathrm{Ab} \\
( \pm 0.14)\end{array}$ & $\begin{array}{c}-0.26 \mathrm{Aa} \\
( \pm 0.14)\end{array}$ & $\begin{array}{c}-0.26 \mathrm{Aa} \\
( \pm 0.04)\end{array}$ & $\begin{array}{c}-0.37 \mathrm{Aab} \\
( \pm 0.10)\end{array}$ \\
\hline Indeterminate & $\begin{array}{c}-0.09 \mathrm{Aa} \\
( \pm 0.04)\end{array}$ & $\begin{array}{c}-0.17 \mathrm{Aab} \\
( \pm 0.06)\end{array}$ & $\begin{array}{c}-0.23 \mathrm{Ab} \\
( \pm 0.09)\end{array}$ & $\begin{array}{c}-0.33 \mathrm{Ba} \\
( \pm 0.09)\end{array}$ & $\begin{array}{c}-0.49 \mathrm{Ba} \\
( \pm 0.12)\end{array}$ & $\begin{array}{c}-0.44 \mathrm{Aa} \\
( \pm 0.16)\end{array}$ \\
\hline
\end{tabular}

(1)Means followed by equal letters, uppercase in the columns and lowercase in the lines, do not differ by the Tukey's test, at 5\% probability. Numbers between parentheses with the signals \pm represent the standard deviation.
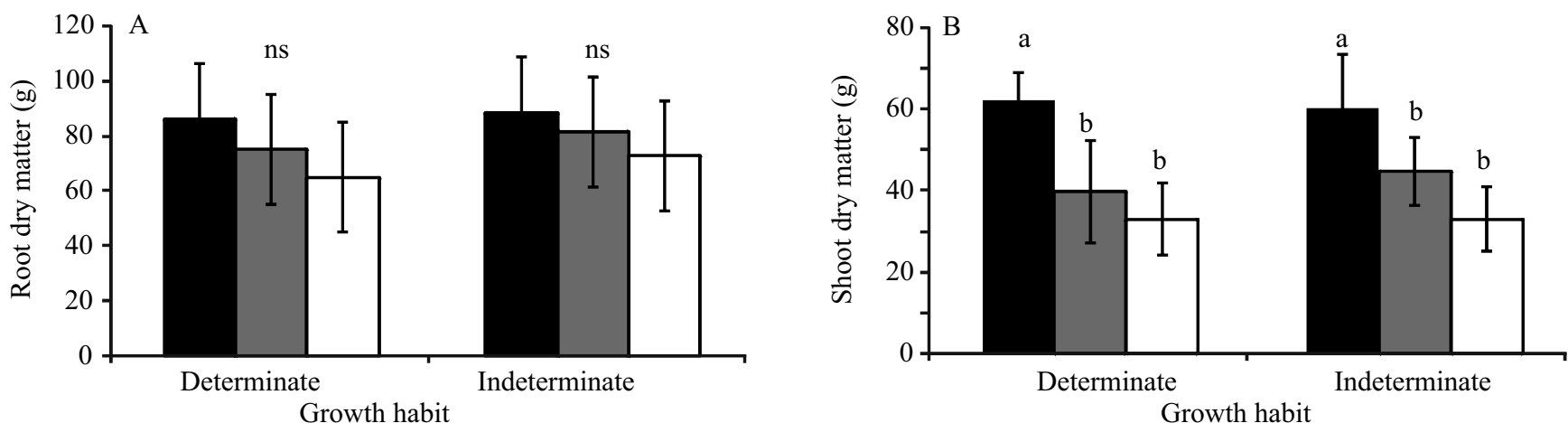

- Control $\square$ Moderate $\square$ Severe

Figure 2. Mass of root (A) and shoot (B) dry matter of soybean cultivars of determinate (UFUS Xavante, UFUS Carajás, and MG/BR 46 Conquista) and indeterminate growth habits (UFUS 6901, BRSMG 772, and BRSMG 7225) subjected to the following treatments: control, soil moisture at field capacity; moderate stress, $50 \%$ of the control soil moisture; and severe stress, $25 \%$ of the control soil moisture. Lowercase letters refer to the effect of soil moisture level. Equal letters do not differ by the Tukey's test, at $5 \%$ probability. ${ }^{\text {nnNonsignificant. }}$ 
accumulation of dry matter, as the yield of dry matter mass is associated with transpiration (Blum, 2009). It is possible to consider that cultivars of indeterminate growth habit consume more water than those of determinate growth, without implying differences for matter mass; threrefore, it can be inferred that the plants of determinate growth habit are more adequate to tolerate water stress than those of indeterminate growth.

No significant differences were observed for chlorophyll content between cultivars of both growth habits; however, there were significant values in response to soil moisture levels, which resulted in: 41.18 , for the control; 37.5 , for the moderate soil moisture; and 36.32 (Falker index), for the severe stress, in which the severe treatment differed from the control. Similar results were found by Inamullah \& Isoda (2005).

No significant differences were observed for grain yield between the two soybean growth habits, which was also not affected by the levels of moderate and severe soil moisture (Table 2). Brevedan \& Egli (2003) applied a severe soil-moisture regime for 13 days to soybean crop, in the pod filling stage, and reported $39 \%$ losses of grain yield; however, those authors used only one soybean cultivar (Elgin 87). Catuchi et al. (2012) reported greater grain yield losses of soybean subjected to severe levels of soil moisture, for a total of 25 days, from flowering to the beginning of pod filling stage. In the present study, plants were subjected to different water regimes for 13 days (beginning of flowering to the beginning of pod set), which allowed of a sufficient time (55 days) for plants to recover until maturation.

Table 2. Grain weight and harvest time of soybean (Glycine max) cultivars of determinate and indeterminate growth habits subjected to different levels of soil moisture (control, moderate, and severe) for 13 days, in the beginning of the reproductive stage.

\begin{tabular}{lcccc}
\hline $\begin{array}{l}\text { Growth } \\
\text { habits }\end{array}$ & \multicolumn{3}{c}{ Grain weight $(\mathrm{g})$} & $\begin{array}{c}\text { Harvest } \\
(\mathrm{DAS})^{(1)}\end{array}$ \\
\cline { 2 - 4 } Determinate & $\begin{array}{l}23.82^{\text {ns }} \\
( \pm 6.58)\end{array}$ & $\begin{array}{l}26.04^{\mathrm{ns}} \\
( \pm 5.54)\end{array}$ & $\begin{array}{l}22.79^{\text {ns }} \\
( \pm 2.61)\end{array}$ & 115 \\
Indeterminate & $\begin{array}{l}30.45^{\text {ns }} \\
( \pm 6.23)\end{array}$ & $\begin{array}{l}29.82^{\text {ns }} \\
( \pm 5.60)\end{array}$ & $\begin{array}{l}29.61^{\text {ns }} \\
( \pm 4.02)\end{array}$ & 105 \\
\hline
\end{tabular}

(1)DAS, days after sowing. Numbers between parentheses with the signals \pm represent the standard deviation. ${ }^{\text {ns }}$ Nonsignificant.

\section{Conclusions}

1. Soybean cultivars of indeterminate growth show greater stomata conductance and $\mathrm{CO}_{2}$ assimilation than the determinate growth ones, when subjected to severe levels of soil moisture.

2. Soybean cultivars of both types of growth habits show no significant changes in the production of dry matter and grain yield, when subjected to severe levels of soil moisture from flowering until pod set.

\section{Acknowledgments}

To Coordenação de Aperfeiçoamento de Pessoal de Nível Superior (Capes), for the scholarship granted; to Empresa Brasileira de Pesquisa Agropecuária (Embrapa), for supplying samples of soybean cultivars; and to Fundação de Amparo à Pesquisa do Estado de Minas Gerais (Fapemig), for financial support.

\section{References}

BERTOLLI, S.C.; RAPCHAN, G.L.; SOUZA, G.M.Photosynthetic limitations caused by different rates of water-deficit induction in Glycine max and Vigna unguiculata. Photosynthetica, v.50, p.329-336, 2012. DOI: 10.1007/s11099-012-0036-4.

BLUM, A. Effective use of water (EUW) and not water-use efficiency (WUE) is the target of crop yield improvement under drought stress. Field Crops Research, v.112, p.119-123, 2009. DOI: 10.1016/j.fcr.2009.03.009.

BREVEDAN, R.E.; EGLI, D.B. Short periods of water stress during seed filling, leaf senescence, and yield of soybean. Crop Science, v.43, p.2083-2088, 2003. DOI: 10.2135/cropsci2003.2083.

CATUCHI, T.A.; GUIDORIZZI, F.V.C.; GUIDORIZI, K.A.; BARBOSA, A. de M.; SOUZA, G.M. Respostas fisiológicas de cultivares de soja à adubação potássica sob diferentes regimes hídricos. Pesquisa Agropecuária Brasileira, v.47, p.519-527, 2012. DOI: $10.1590 /$ S0100-204X2012000400007.

FAO. Food and Agriculture Organization of the United States. Faostat. 2012. Available at: <http://faostat.fao.org/site/339/ default.aspx $>$. Accessed on: May 82014.

FEHR, W.R.; CAVINESS, C.E. Stages of soybean development. Ames: Iowa State University, 1977. 12p.

FENTA, B.A.; DRISCOLL, S.P.; KUNERT, K.J.; FOYER, C.H. Characterization of drought-tolerance traits in nodulated soya beans: the importance of maintaining photosynthesis and shoot biomass under drought-induced limitations on nitrogen metabolism. Journal of Agronomy and Crop Science, v.198, p.92-103, 2012. DOI: 10.1111/j.1439-037X.2011.00491.x.

GILBERT, M.E.; HOLBROOK, N.M.; ZWIENIECKI, M.A.; SADOK, W.; SINCLAIR, T.R. Field confirmation of genetic variation in soybean transpiration response to vapor pressure 
deficit and photosynthetic compensation. Field Crops Research, v.124, p.85-92, 2011. DOI: 10.1016/j.fcr.2011.06.011.

HUANG, L.F.; ZHENG, J.H.; ZHANG, Y.Y.; HU, W.H.; MAO, W.H.; ZHOU, W.H.; YU, J.Q. Diurnal variations in gas exchange, chlorophyll fluorescence quenching and light allocation in soybean leaves: the cause for midday depression in $\mathrm{CO}_{2}$ assimilation. Scientia Horticulturae, v.110, p.214-218, 2006. DOI: 10.1016/j. scienta.2006.07.001.

IBGE. Instituto Brasileiro de Geografia e Pesquisa. Levantamento sistemático da produção agrícola. 2016. Available at: <http:// www.ibge.gov.br/home/estatistica/indicadores/agropecuaria/ lspa/lspa_201608_5.shtm>. Accessed on: Sept. 152016.

INAMULLAH, I.; ISODA, A. Adaptive responses of soybean and cotton to water stress. II. Changes in $\mathrm{CO}_{2}$ assimilation rate, chlorophyll fluorescence and photochemical reflectance index in relation to leaf temperature. Plant Production Science, v.8, p.131138, 2005. DOI: 10.1626/pps.8.131.

KRAUSE, G.H.; WEIS, E. Chlorophyll fluorescence and photosynthesis: the basics. Annual Review of Plant Physiology and Plant Molecular Biology, v.42, p.313-349, 1991. DOI: 10.1146/annurev.arplant.42.1.313.

LAMBERS, H.; CHAPIN III, F.S.; PONS, T.L. Plant physiological ecology. $2^{\text {nd }}$ ed. New York: Springer-Verlag, 2008. DOI: $10.1007 / 978-0-387-78341-3$.

LI, D.; LIU, H.; QIAO, Y.; WANG, Y.; CAI, Z.; DONG, B.; SHI, C.; LIU, Y.; LI, X.; LIU, M. Effects of elevated $\mathrm{CO}_{2}$ on the growth, seed yield, and water use efficiency of soybean [Glycine max (L.) Merr.] under drought stress. Agricultural Water Management, v.129, p.105-112, 2013. DOI: 10.1016/j.agwat.2013.07.014.

LIU, F.; ANDERSEN, M.N.; JACOBEN, S.-E.; JENSEN, C.R. Stomatal control and water use efficiency of soybean (Glycine $\max$ L. Merr.) during progressive drying. Environmental and Experimental Botany, v.54, p.33-40, 2005. DOI: 10.1016/j. envexpbot.2004.05.002.

MADHU, M.; HATFIELD, J.L. Interaction of carbon dioxide enrichment and soil moisture on photosynthesis, transpiration, and water use efficiency of soybean. Agricultural Sciences, v.5, p.410-429, 2014. DOI: 10.4236/as.2014.55043.
PERINI, L.J.; FONSECA JÚNIOR, N. da S.; DESTRO, D.; PRETE, C.E.C. Componentes da produção em cultivares de soja com crescimento determinado e indeterminado. Semina: Ciências Agrárias, v.33, p.2531-2544, 2012. DOI: 10.5433/1679-0359.2012v33Supl1p2531.

PRASAD, P.V.V.; PISIPATI, S.R.; MUTAVA, R.N.; TUINSTRA, M.R. Sensitivity of grain sorghum to high temperature stress during reproductive development. Crop Science, v.48, p.19111917, 2008. DOI: 10.2135/cropsci2008.01.0036.

RIGON, J.P.G.; CAPUANI, S.; BELTRÃO, N. de E.M.; BRITO NETO, J.F.; SOFIATTI, V.; FRANÇA, F.V. Non-destructive determination of photosynthetic pigments in the leaves of castor oil plants. Acta Scientiarum. Agronomy, v.34, p.325-329, 2012. DOI: 10.4025/actasciagron.v34i3.13872.

SILVA, F.A.S.; AZEVEDO, C.A.V. Principal components analysis in the software Assistat-Statistical Attendance. In: WORLD CONGRESS ON COMPUTERS IN AGRICULTURE, 7., 2009, Reno. [Proceedings...]. [St. Joseph]: American Society of Agricultural and Biological Engineers, 2009. Available at: $<$ http:// www.assistat.com/indexp.html >. Accessed on: Apr. 282016.

SINCIK, M.; CANDOGAN, B.N.; DEMIRTAS, C.; BÜYÜKCANGAZ, H.; YAZGAN, S.; GÖKSOY, A.T. Deficit irrigation of soya bean [Glycine $\max$ (L.) Merr.] in a sub-humid climate. Journal of Agronomy and Crop Science, v.194, p.200205, 2008. DOI: 10.1111/j.1439-037X.2008.00307.x.

SINCLAIR, T.R.; HAMMER, G.L.; OOSTEROM, E.J. van. Potential yield and water-use efficiency benefits in sorghum from limited maximum transpiration rate. Functional Plant Biololgy, v.32, p.945-952, 2005. DOI: 10.1071/FP05047.

TANAKA, Y.; SHIRAIWA, T. Steam growth habit affects leaf morphology and gas exchange traits in soybean. Annals of Botany, v.104, p.1293-1299, 2009. DOI: 10.1093/aob/mcp240.

VILLALOBOS-RODRIGUES, E.; SHIBLES, R. Response of determinate and indeterminate tropical soybean cultivars to water stress. Field Crops Research, v.10, p.269-281, 1985. DOI: 10.1016/0378-4290(85)90033-4.

Received on April 28, 2016 and accepted on November 9, 2016 